UDC: 334.024:808.51

DOI: 10.26697/ijes.2019.4.43

\section{Contemporary Role of Media Literacy}

Associate Professor Stepanenko N. O. ${ }^{\mathbf{1}}$, Associate Professor Klimenko O. M. ${ }^{1}$

${ }^{1}$ Simon Kuznets Kharkiv National University of Economics, Ukraine

\begin{abstract}
Background:

Media technology tends to make its greatest advances in meeting the changing needs of consumers, as illustrated by the exponential increase we see in the processing power of the computer every day.

Media literacy is an ambitious goal, since it covers both the content of traditional media and the representation of the image, as well as the appropriate using of new technologies.

Over the years, technology has revolutionized our world. Technology has created incredible tools and resources, putting useful information in peoples' hands. When it comes to the way people communicate, modern technology has had an impressive influence. Digital technology has also changed what people call "media".

The influence of the new technology in the media is an evident since a media company is no longer necessarily a news platform. A media company is now known as a company that helps pass information to everyone. That is why nowadays it's becoming crucial to do some researches to discover necessity of media literacy.

The aim of the research is to study essence and contemporary role of media literacy.
\end{abstract}

\section{Methods:}

A complex of theoretical research methods has been used: analysis and synthesis, comparison, generalization.

\section{Results:}

Media literacy is the ability to identify different types of media and the messages they are sending. Therefore, we as the readers or viewers need to get information from the media objectively, with the goal to find out or analyze what is being presented.

One of the main reasons why media literacy is important is because it develops critical thinking skills from childhood.

Media literacy concerns different media (broadcasting, radio, press), different distribution channels (traditional, internet, social media) and addresses the needs of all ages. Media literacy is also a tool empowering people as well as raising their awareness and helping counter the effects of disinformation campaigns and fake news spreading through digital media.

Nowadays all people may have some form of social media platform on Facebook or Twitter, and they also may have their own ways of communicating across the web. While communication channels remain unique, there is a great responsibility in the intelligent using one's platform. The current problems in modern society, mainly political, are widely discussed in today's media.

Media literacy, our capacity to access, have a critical understanding of, and interact with the media has never been as important as in today's society. It enables people of all ages to navigate the modern news environment and take informed decisions.

The media can present content that seems and is more or less real, however, it is our duty as the viewers to be able to distinguish, and differentiate between "reflections of reality, and constructions of reality".

Media literacy can be considered as the process of accessing, critically analyzing media messages, and creating messages using media tools. A lot of people view that media literacy facilitates understanding of communication technology, the message code, message selection, interpretation, and impact of the message on the receiver.

\section{Conclusions:}

Media literacy is becoming very important, as it sets perspectives to interpret the meaning of the mediated messages so that it can provide clues about how to treat the media - in the context of this paper, this refers to the online social media.

The freedom of delivering messages on social media should be appropriately filtered to preserve the societal norms and values.

\section{Information about the authors: \\ Stepanenko Nataliia Oleksiivna - Candidate of Sciences (Economics), Associate Professor of Economic Theory and Policy Department, Simon Kuznets Kharkiv National University of Economics, Kharkiv, Ukraine. \\ Research interests: globalization, European integration, social wellbeing; https://orcid.org/0000- 0003-4643-1677. \\ Klimenko Olena Mikolaivna - Candidate of Sciences (Economics), Associate Professor of Economic Theory and Policy Department, Simon Kuznets Kharkiv National University of Economics, Kharkiv, Ukraine. Research interests: environmental economy, globalization, economic policy, state regulation of economy; https://orcid.org/0000-0002-2573-9333.}

\section{Corresponding Author:}

Stepanenko Nataliia Oleksiivna

\section{Corresponding Author's Email:}

snatik75@gmail.com 